Chi-Yuan Li MD MS, * Tz-Chong Chou PhD, ${ }^{\dagger}$ Chih-Shung Wong MD PhD, * Shung-Tai Ho MD, * Chin-Chen Wu PhD, ${ }^{\ddagger}$ Mao-Hsiung Yen PhD, $\ddagger$ Yu-An Ding $M D \mathrm{PhD}^{\$}$

\section{Ketamine inhibits nitric oxide synthase in lipopolysaccharide-treated rat alveolar macrophages}

Purpose: To evaluate the effects of ketamine on the activity and protein expression of inducible nitric oxide synthase (NOS) induced by lipopolysaccharide (LPS) in rat alveolar macrophages.

Methods: Pulmonary alveolar macrophages isolated from Wistar-Kyoto rats were used. After incubation of macrophages with ketamine $(1,10$, or $100 \mu \mathrm{M})$ and $\mathrm{LPS}\left(1 \mu \mathrm{g} \cdot \mathrm{ml}^{-1}\right)$ for $24 \mathrm{hr}$, the cell-free medium was removed for measuring the nitrite and tumour necrosis factor- $\alpha$ (TNF- $\alpha$ ) levels by Griess reaction and ELISA kit, respectively. The harvested macrophages were also used to determine the activity of iNOS by using the conversion of $\left[{ }^{3} \mathrm{H}\right]$-L-arginine to $\left[{ }^{3} \mathrm{H}\right]-\mathrm{L}$-citrulline method. In addition, the protein expression of $\mathrm{iNOS}$ was detected by Western blot analysis.

Results: In rat alveolar macrophages, (I) ketamine (I to $100 \mu \mathrm{M}$ ) caused a dose-dependent suppression of the production of nitrite and TNF- $\alpha$ induced by LPS and (ii) ketamine $(100 \mu \mathrm{M})$ inhibited the activity $(46.5 \pm 4.8 \%$. $P<0.05)$ and protein expression $(35 \pm 11 \%, P<0.05)$ of iNOS in response to LPS.

Conclusion: These results show that ketamine inhibits the activity and expression of iNOS in LPS-activated alveolar macrophages, which may be associated with the reduction of the release of TNF- $\alpha$ following LPS treatment.

Objectif : Évaluer les effets de la kétamine sur l'activité et la production de l'oxyde nitrique synthase inductible (iNOS) par le lipopolysaccharide (LPS) sur des macrophages alvéolaires de rats.

Méthodes : Des macrophages alvéolaires pulmonaires isolés chez des rats Wistar-Kyoto ont été utilisés. Après l'incubation des macrophages dans la kétamine (1,10 ou $100 \mu \mathrm{M})$ et le LPS $\left(1 \mu \mathrm{g}^{\prime} \mathrm{kg}^{-1}\right)$ pendant $24 \mathrm{~h}$, le médium libre de cellules a été extrait pour mesurer les niveaux nitriques et de TNF- $\alpha$ (tumour necrosing factor- $\alpha$ ) avec la réaction de Griess et par ELISA. La méthode de conversion de la [3H]-L-arginine à la [3H]-L-citrulline à servi à déterminer l'activité iNOS des macrophages recueillis. En outre, l'analyse Westem blot décelait l'expression protéinique de iNOS.

Résultats : Dans les macrophages alvéolaires de rats, (i) la kétamine (là $100 \mu \mathrm{M}$ ) a provoqué une suppression dépendante de la dose de la production de nitrite et de TNF- $\alpha$ induite par LPS et (ii) la kétamine (100 $\mu \mathrm{M}$ ) inhibait l'activité $(46,5 \pm 4,8 \%, P<0,05)$ et l'expression protéinique $(35=11 \%, P<0,05)$ de l'iNOS en réponse au LPS.

Conclusion : Ces résultats montrent que la kétamine inhibe l'activité et la production de linOS dans des macrophages alvéolaires activés par LPS, ce qui peut être associé à une réduction de la libération de TNF- $\alpha$ à la suite d'un traitement par LPS.

From the Departments of Anesthesiology, ${ }^{*}$ Medical Research, ${ }^{\dagger}$ Pharmacology, ${ }^{\ddagger}$ Medicine $\$$ and Graduate Institute of Medical Sciences, ${ }^{\text {t\$ }}$

Tri-Service General Hospital, National Defense Medical Center, 8, Sec 3, Ting-Chow Rd., Taipei, Taiwan, Republic of China. Address correspondence to: Dr. Chi-Yuan Li, Department of Anesthesiology.

Phone: 886-2-365-0729; Fax: 886-2-365-4670; E-mail: cyli@ndmcl.ndmctsgh.edu.tw

Supported by a grant of the Tri-service General Hospital, Taipei, Taiwan, R. O. C. (TSGH-C86-50). Accepted for publication June 15, 1997. 


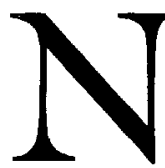

ITRIC Oxide (NO) is now recognized as a vasodilator, a neurotransmitter, and an immunomodulator. ${ }^{1}$ Endogenous NO is produced by the enzyme nitric oxide synthase (NOS) in which oxygen combines with the terminal quanidino nitrogen of the amino acid $\mathrm{L}$-arginine to produce NO and equal amount of L-citrulline. Three different isoforms of NOS (endothelial, neuronal and inducible) have been isolated and their genes have been cloned. ${ }^{2,3}$ The endothelial and neuronal types of NOS are constitutive isoforms and calcium dependent, and NO produced by both enzymes mediates many physiological responses. The inducible nitric oxide synthase (iNOS) in macrophages, hepatocytes, and vascular smooth muscle cells is generally a calcium-independent enzyme and is expressed only under pathological conditions. ' For instance, when macrophages are activated by stimuli such as bacterial toxins (lipopolysaccharide, LPS) or cytokines (tumour necrosis factor- $\alpha$, TNF- $\alpha$; interleukin-1, IL-1; interferon- $\gamma$ ), ${ }^{4,5}$ transcription of the iNOS gene is activated and NOS enzyme is produced. Once iNOS is activated, iNOS continuously releases large amounts of NO. Nitric oxide is also a cytotoxic molecule which kills bacteria and tumour cells. Thus, induction of $\mathrm{NOOS}$ in macrophages plays important roles in host defense and immunological function. ${ }^{6}$ Enhanced formation of NO following induction of iNOS contributes importantly to the circulatory failure and cardiovascular dysfunction, such as vasodilatation, severe hypotension and vascular hyporeactivity to vasoconstrictor agents, in various animal models of septic shock. ${ }^{7}$

Ketamine, a phencyclidine derivative, has been recommended for the induction of anaesthesia and sedation in patients with circulatory shock because of its actions in increasing sympathetic nervous system activity, to maintain blood pressure, and in preserving cardiovascular function. ${ }^{8-11}$ In addition, a recent study demonstrated that ketamine suppressed TNF- $\alpha$ production induced by endotoxin in cultured macrophages and inhibited NO-dependent cGMP production in cultured cerebral neuron. ${ }^{12,13}$ More recently, ketamine has been reported to inhibit accumulation of nitrite, one of the metabolites of NO, dose-dependently in LPS-activated macrophages. ${ }^{14}$ However, it is unclear whether the inhibition of NO production caused by ketamine is associated with inhibition of induction of iNOS. In the present study, we examined this hypothesis by measuring the activity and expression of iNOS in rat alveolar macrophages activated by LPS.

\section{Methods}

\section{Preparation of macrophages}

This study was approved by our Institutional Animal Care and Use Committee. Adult male Wistar-Kyoto rats $(250-350 \mathrm{~g})$ were deeply anaesthetized with an overdose of sodium pentobarbital $\left(75 \mathrm{mg} \cdot \mathrm{kg}^{-1}, i p\right)$. The trachea was exposed and cannulated with a catheter. The lungs were gently lavaged with $5 \mathrm{ml}$ each of phosphate buffer solution (PBS) $\left(4^{\circ} \mathrm{C}\right)$ five-six times. The combined lavage fluid was centrifuged at $200 \mathrm{~g}$ for five minutes at $4^{\circ} \mathrm{C}$. The supernatant was discarded, and the macrophages were resuspended either in 24-well plates $\left(5 \times 10^{5}\right.$ cells per well) (Costar, Cambridge, MA) at $0.6 \mathrm{ml} \cdot \mathrm{well}^{-1}$ or in $10 \mathrm{~cm}$ dish ( $10^{7}$ cells per dish ) (Becton Dickinson, Lindoln Park, NJ) at 4 ml-well ${ }^{-1}$ in RPMI 1640 (Gibco, Grand Island, NY) with $10 \%$ heat-inactivated fetal bovine serum (JRH Biosciences, Lenexa, KS), penicillin (100 $\left.\mathrm{U} \cdot \mathrm{ml}^{-1}\right)$ and streptomycin $\left(100 \mathrm{mg} \cdot \mathrm{ml}^{-1}\right)$. After three hours incubation, unattached macrophages were removed. The fresh medium either containing $E$. coli LPS $\left(1 \mu \mathrm{g} \cdot \mathrm{ml}^{-1}\right)$ (Sigma, serotype No. 0127-B8) alone or with ketamine (1 to $100 \mu \mathrm{M}$ ) (Sigma, St. Louis, $\mathrm{MO}$ ) was added then incubated at $37^{\circ} \mathrm{C}, 5 \% \mathrm{CO}_{2}$ in humidified air for $24 \mathrm{hr}$. An aliquot of the conditioned medium was removed for assays of nitrite and TNF- $\alpha$.

The macrophages were washed and scraped into cold PBS, and were centrifuged at $200 \mathrm{~g}$ for five minutes at $4^{\circ} \mathrm{C}$. The cell pellet was frozen at $-70^{\circ} \mathrm{C}$ for later processing, or resuspended in $200 \mu$ l sonication buffer Tri-HCl $(50 \mathrm{mM}, \mathrm{pH} 7.4)$ containing EDTA $(0.1 \mathrm{mM})$, EGTA $(0.1 \mathrm{mM})$ and phenylmethylsulphonylfluoride $(1 \mathrm{mM})$ at $4^{\circ} \mathrm{C}$. The cell pellet was sonicated (Heat systems, Inc. Famingdale, NY) as follows: $50 \%$ duty cycle, $10 \mathrm{sec}$ each intensities of 1,2 and 3 . An aliquot of the whole lysate was centrifuged at $10,000 \mathrm{~g}$ for $30 \mathrm{~min}$ at $4^{\circ} \mathrm{C}$. The supernatant was collected for the determination of iNOS activity and Western blot analysis. The protein content was measured by Biorad protein assay method.

\section{Measurement of nitrite and TNF- $\alpha$}

Accumulated nitrite levels were determined by mixing $100 \mu \mathrm{l}$ of cell culture medium with $100 \mu \mathrm{l}$ of Griess reagent (sulphanilamide $1 \%$ and naphthylethylene diamide $0.1 \%$ in phosphoric acid $5 \%$ ), incubating the mixture at room temperature for $15 \mathrm{~min}$, and then determining the absorbance at $550 \mathrm{~nm}$ in a MRX microplate reader (Dynatech, Guernsey, UK). Fresh culture medium served as the blank, and solutions of $\mathrm{NaNO}_{2}$ diluted in culture medium were used as standards. The amounts of TNF- $\alpha$ in the cultured medium were measured by a rat TNF- $\alpha$ ELISA kit (Genzyme Corporation, Cambridge, MA). The minimal detection limits of this assay is $10 \mathrm{pg} \cdot \mathrm{ml}^{-1}$. The specificity of the TNF- $\alpha$ kit shows no cross-reactivity with other cytokines even with the highest concentration $1 \mu \mathrm{g} \cdot \mathrm{ml}^{-1}$. 


\section{NOS activity assay}

The NOS activity was determined by measuring the conversion of $\left[{ }^{3} \mathrm{H}\right]$ - $\mathrm{L}$-arginine to $\left[{ }^{3} \mathrm{H}\right]-\mathrm{L}$-citrulline. The supernatant $(20 \mu \mathrm{l}$, approximately $60 \mu \mathrm{g}$ protein) was incubated in HEPES buffer $(20 \mathrm{mM}$, pH 7.5) containing L-arginine $(10 \mu \mathrm{M})$ and $\left[{ }^{3} \mathrm{H}\right]-\mathrm{L}$ arginine $\left(3 \mu \mathrm{Ci} \cdot \mathrm{ml}^{-1}\right)$, L-valine $(60 \mathrm{mM})$, NADPH (1 $\mathrm{mM}$ ), calmodulin (30 $\mathrm{nM})$, tetrahydrobiopterin $(5 \mu \mathrm{M})$ and calcium $(2 \mathrm{mM})$ for $20 \mathrm{~min}$ at $25^{\circ} \mathrm{C}$. The reaction was stopped by adding $1 \mathrm{ml}$ ice-cold HEPES buffer ( $\mathrm{pH} 5.5$ ) containing EGTA $(2 \mathrm{mM})$ and EDTA ( $2 \mathrm{mM})$. Reaction mixture was applied to Dowex 50W $\left(\mathrm{Na}^{+}\right.$form) columns. This resin allows citrulline (neutral amino acid) to elute while arginine (cationic[+] charge) is bound. Columns were then rinsed with $2 \times 1 \mathrm{ml}$ HEPES buffer $(\mathrm{pH}$ $5.5)$ to ensure complete elution of citrulline. The amount of $\left[{ }^{3} \mathrm{H}\right]-\mathrm{L}$ - citrulline eluted was quantified by liquid scintillation spectroscopy (Beckman, LS3801, Orange county, CA) with an efficiency of $90-94 \%$. The activity of NOS is expressed as pmol of $\left[{ }^{3} \mathrm{H}\right]$-L-citrulline produced per $\mathrm{mg}$ of protein. Experiments performed in the absence of NADPH were to determine the extent of $\left[{ }^{3} \mathrm{H}\right]$-L-citrulline formation of independent of NOS activity. The activity of the $\mathrm{Ca}^{2+}$-independent iNOS activity was determined from the difference between samples containing $2 \mathrm{mM}$ EGTA and samples without NADPH. ${ }^{15}$

\section{Western blotting}

Cell lysate containing $10 \mu \mathrm{g}$ protein was denatured and an equal amount of protein loaded on 7.5\% SDS-PAGE gel using PhastSystem with PhastGel (Pharmacia Biotech, Uppsala, Sweden). Separated proteins were transferred to nitrocellulose membranes using PharmTransfer Semi-Dry transfer kit (Pharmacia Biotech, Uppsala, Sweden). The membranes were blocked with $1 \%$ BSA in Tris-buffer solution (TBS) $\mathrm{pH}=8.0$ containing Tween $-20,0.1 \%$, for two hours at room temperature and then incubated with mouse monoclonal anti-iNOS antibody (1: 2000 dilution, Transduction Laboratories, Lexington, $\mathrm{KY}$ ) in TBS containing Tween-20, $0.1 \%$, for $12 \mathrm{hr}$ at $4^{\circ} \mathrm{C}$. The membrane was washed and finally incubated with a 1:1,000 dilution of anti-mouse IgG conjugated to horseradish peroxidase for two hours at room temperature. After successive washes with TBS, the immunocomplexs were detected using an enhanced horseradish peroxidase/luminol chemiluminescence reaction (Amersham International plc, Buckinghamshire, UK) and exposed to $\mathrm{X}$-ray film for two to three minutes. The relative expression of iNOS protein in cell lysate was quantified by densitometric scanning of the Western blots using Image-pro plus software.

\section{Cell respiration}

Cell respiration, an indicator of cell viability, was assessed by mitochondria-dependent reduction of MTT [3-(4, 5-dimethylthiazol-2-yl)-2.5-diphenyltetrazolium bromide] to formazan. ${ }^{16}$ After incubating with either the LPS alone or with various concentration of ketamine $(1,10,100 \mu \mathrm{M})$ for $24 \mathrm{hr}$, cells were incubated with MTT in a concentration of $0.3 \mathrm{mg} \cdot \mathrm{ml}^{-1}$ for two hours at $37^{\circ} \mathrm{C}$. Cultured medium was removed by aspiration and cells were treated with dimethylsulphoxide for $30 \mathrm{~min}$. The plates were read on a MRX spectrophotometer (Dynatech, Guernsey, UK) at a wavelength of $550 \mathrm{~nm}$.

\section{Statistics}

Data are expressed as mean \pm SEM. Quantities of nitrite and TNF- $\alpha$ were compared by applying oneway ANOVA followed by a multiple comparison test (Scheffe's test). Unpaired Student' $s$ test was used for NOS activity and protein expression. A $P<0.05$ was considered statistically significant.

\section{Results}

Ketamine attenuates the increase in nitrite and TNF- $\alpha$ caused by LPS

The baseline value of nitrite and TNF- $\alpha$ levels in the medium of control groups was $6.4 \pm 1.0 \mu \mathrm{M}$ and $70 \pm 10 \mathrm{pg} \cdot \mathrm{ml}^{-1}$, respectively. Activation of alveolar macrophages with LPS $\left(1 \mu \mathrm{g} \cdot \mathrm{ml}^{-1}\right)$ resulted in an increase in nitrite concentration $(46.4 \pm 1.8 \mu \mathrm{M})$ and TNF- $\alpha$ level $\left(13.1 \pm 0.5 \mathrm{ng} \cdot \mathrm{ml}^{-1}\right)$ in the medium after $24 \mathrm{hr}$. Administration of the macrophages with ketamine ( 1 to $100 \mu \mathrm{M}$ ) reduced the increment of nitrite and TNF- $\alpha$ levels in a concentration-dependent manner, and the concentrations of ketamine had no effects on cell respiration (Figures 1,2).

\section{Ketamine attenuates the activity of $i N O S$}

The basal iNOS activity in untreated alveolar macrophages was $15 \pm 5.6 \mathrm{pmol} \cdot \mathrm{min}^{-1} \cdot \mathrm{mg}^{-1}$ protein. After alveolar macrophages were incubated with LPS $\left(1 \mu \mathrm{g} \cdot \mathrm{ml}^{-1}\right)$ for $24 \mathrm{hr}$, the iNOS activity was increased to $44.1 \pm 6.5 \mathrm{pmol} \cdot \mathrm{min}^{-1} \cdot \mathrm{mg}^{-1}$ protein. Co-treatment of macrophages with ketamine $(100 \mu \mathrm{M})$ and LPS caused a reduction $\left(23.6 \pm 4.4 \mathrm{pmol} \cdot \mathrm{min}^{-1} \cdot \mathrm{mg}^{-1}\right.$ protein $)$ in NOS activity $(P<0.05, v s$ LPS alone) (Figure 3$)$.

\section{Ketamine attenuates the expression of $i N O S$}

Untreated pulmonary alveolar macrophages contained little detectable iNOS protein as determined by Western blot analysis (Figure 4). After stimulated macrophages with LPS (l $\left.\mu \mathrm{g} \cdot \mathrm{ml}^{-1}\right)$ for $24 \mathrm{hr}$, the iNOS expression was augmented. Co-treatment of macrophages with LPS and ketamine $(100 \mu \mathrm{M})$ 


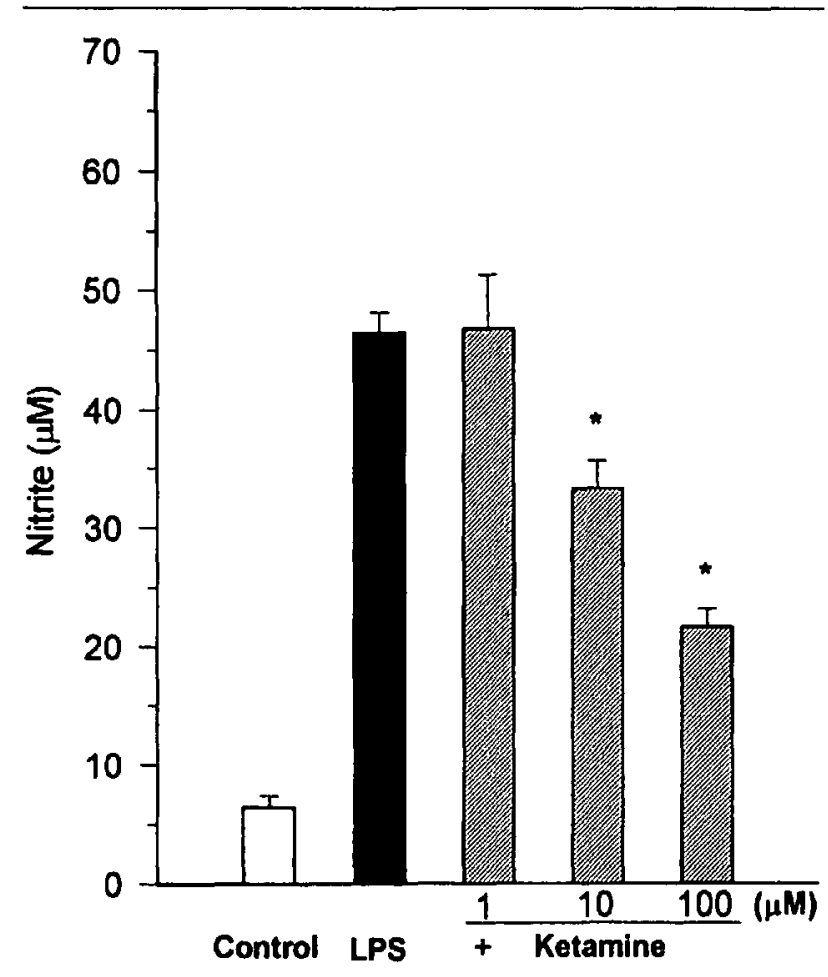

FIGURE 1 Ketamine causes a concentration-dependent inhibition of nitrite formation induced by LPS in rat alveolar macrophages. LPS $\left(1 \mu \mathrm{g} \cdot \mathrm{ml}^{-1}\right)$ or LPS plus ketamine $(1-100 \mu \mathrm{M})$ were added into the macrophages for $24 \mathrm{hr}$. Values are expressed as mean \pm SEM of 8-12 observations from three different cell culture plates

${ }^{*} P<0.01$ vs LPS alone

resulted in a marked decrease $(35 \pm 11 \%)$ in iNOS protein expression $(P<0.05, p s$ LPS alone).

\section{Discussion}

Activation of macrophages with LPS and/or cytokines results in accumulation of nitrite, one of the metabolites of NO. This accumulation of nitrite reflects an enhanced formation of NO via the induction of iNOS by LPS in these cells. In the present study, we found that accumulation of nitrite was inhibited by ketamine in a concentration-dependent manner. Similar findings have recently been reported in mouse-activated macrophage-like cells. ${ }^{14}$ From these data, we suggest that the reduction of NO formation by ketamine is due to the inhibition of iNOS induction.

We first demonstrated that ketamine attenuated the expression of iNOS protein as well as the activity of iNOS in rat cultured alveolar macrophages stimulated with LPS. Although the mechanisms of the inhibitory effects of ketamine on the iNOS are still unclear, one of the possible mechanisms might be associated with the release of cytokines such as TNF- $\alpha$ or IL-1. These

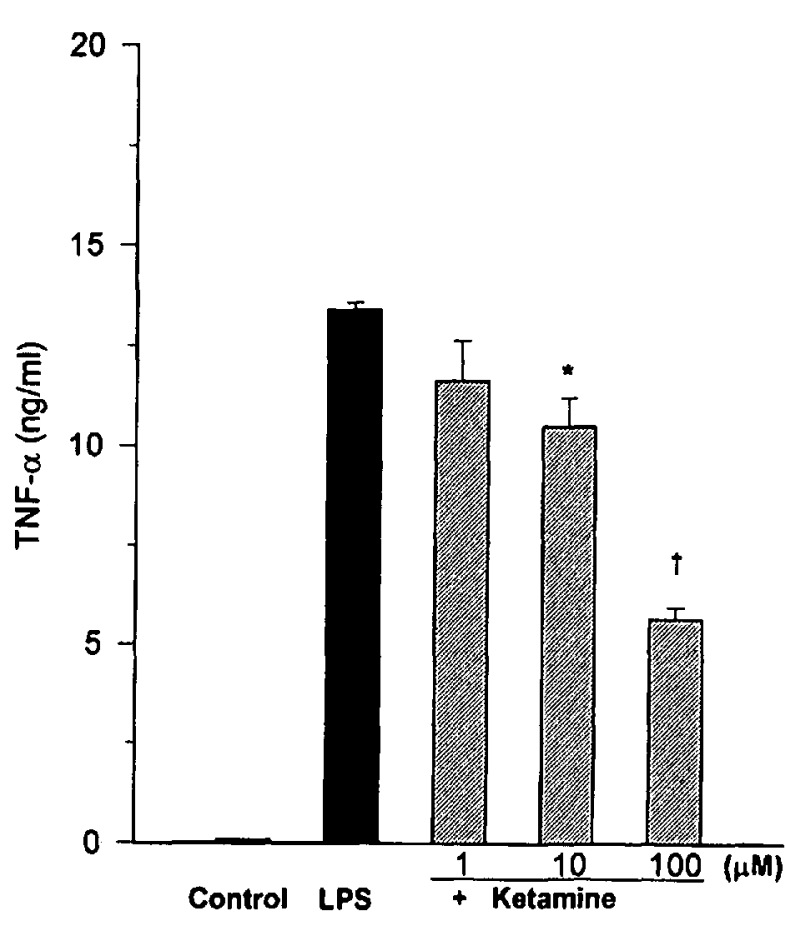

FIGURE 2 Ketamine causes a concentration-dependent inhibition of TNF- $\alpha$ production induced by LPS in rat alveolar macrophages. LPS $\left(1 \mu \mathrm{g} \cdot \mathrm{ml}^{-1}\right)$ or LPS plus ketamine $(1-100 \mu \mathrm{M})$ were added into the macrophages for $24 \mathrm{hr}$. Values are expressed as mean \pm SEM of 8-12 observations from three different cell culture plates

${ }^{*} P<0.05{ }^{\dagger} P<0.01 \mathrm{vs}$ LPS alone

cytokines have been shown to mediate the induction of iNOS in rats with endotoxaemia. ${ }^{17,18}$ For instance, Thiemerman $e t a l$. described that TNF- $\alpha$ antibodies prevented the induction of iNOS in rats with endotoxaemia. ${ }^{17}$ Similarly, other inhibitors of iNOS induction including dexamethasone and dihydropyridine-type calcium channel antagonists has been shown to suppress the formation of nitrite and the release of TNF- $\alpha .^{19-23}$ Thus, their results suggest that the reduction of release of TNF- $\alpha$ may be one of the mechanisms by which ketamine inhibits the expression and activity of iNOS. Here, our data also demonstrated that ketamine dosedependently inhibited the production of TNF- $\alpha$ and prevented the induction of iNOS in cultured alveolar macrophages challenged with LPS. The former findings are similar to the previous reports by Takenaka $e t a l$. and Shimaoka $e t a l .^{12,14}$ All the results suggest that the reduction of TNF- $\alpha$ is associated, at least in part, with inhibition of iNOS expression and activity in the rat alveolar macrophage.

Pretreatment of macrophages with LPS in the presence of calcium ionophore causes a four-fold increment of 


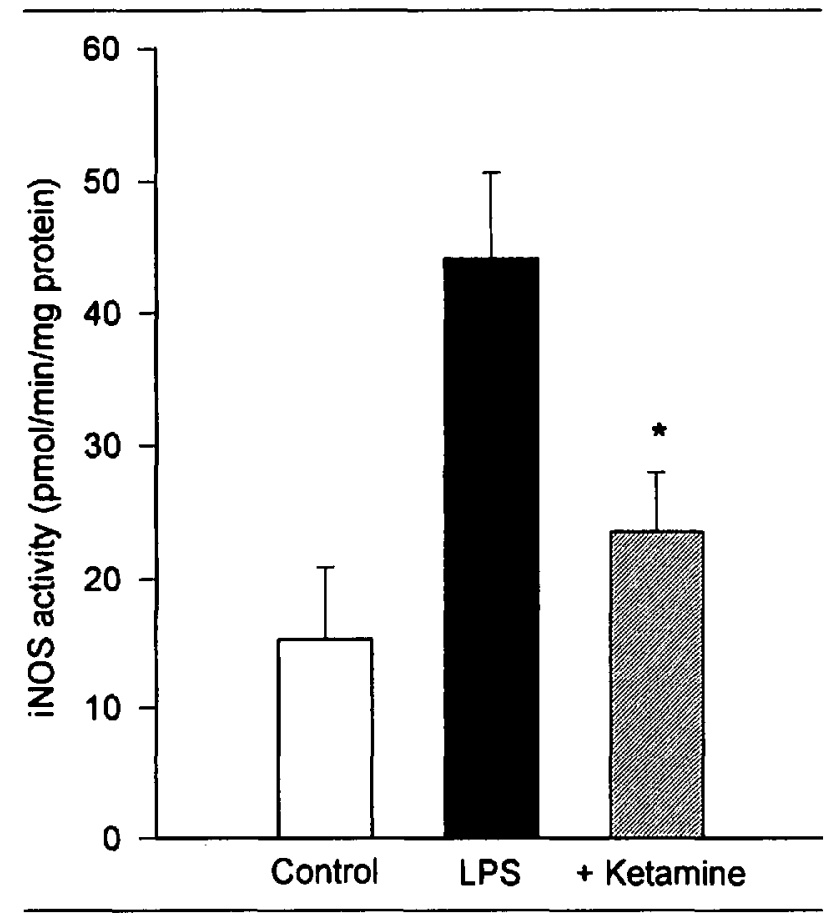

FIGURE 3 Effects of ketamine on iNOS activity in the LPSstimulated rat alveolar macrophages. Calcium-independent iNOS activity was measured in the supernatant of macrophages un-stimulated (control; $n=3$ ), treated with LPS $\left(1 \mu \mathrm{g} \cdot \mathrm{ml}^{-1}\right)$ (LPS; $n=3$ ) or co-treated with LPS and ketamine $(100 \mu \mathrm{M})(+$ ketamine; $n=3)$ for $24 \mathrm{hr}$.

$* P<0.05$ vs LPS alone.

NO production. ${ }^{24}$ In addition, Denlinger et al. demonstrated that the expression of iNOS was regulated by calcium. ${ }^{25}$ Thus, calcium is critical for the production of inflammatory mediators and the induction of iNOS in macrophages stimulated with LPS. The inhibition of iNOS induction by ketamine may be related to interference of calcium mobilization, a suggestion which is based on our recent studies of dantrolene, an inhibitor of calcium release from sarcoplasmic reticulum, that prevents induction of iNOS in the rat. ${ }^{26}$ However, the effects of ketamine on calcium concentration in alveolar macrophages need to be further clarified.

Recent murine studies have demonstrated that ketamine has beneficial effects. For instance, it inhibits leukocyte adherence to endothelial cells in postcapillary venules during endotoxaemia and has a neuronal protective effect by suppressing NO production during cerebral ischaemia. ${ }^{27,28}$ In addition, ketamine suppresses TNF- $\alpha$ production from macrophages challenged with endotoxin in vitro and in vipo. ${ }^{12}$ In this study, we have demonstrated that ketamine inhibited the overproduction of NO by attenuating the activity and expression of iNOS as well as the levels of

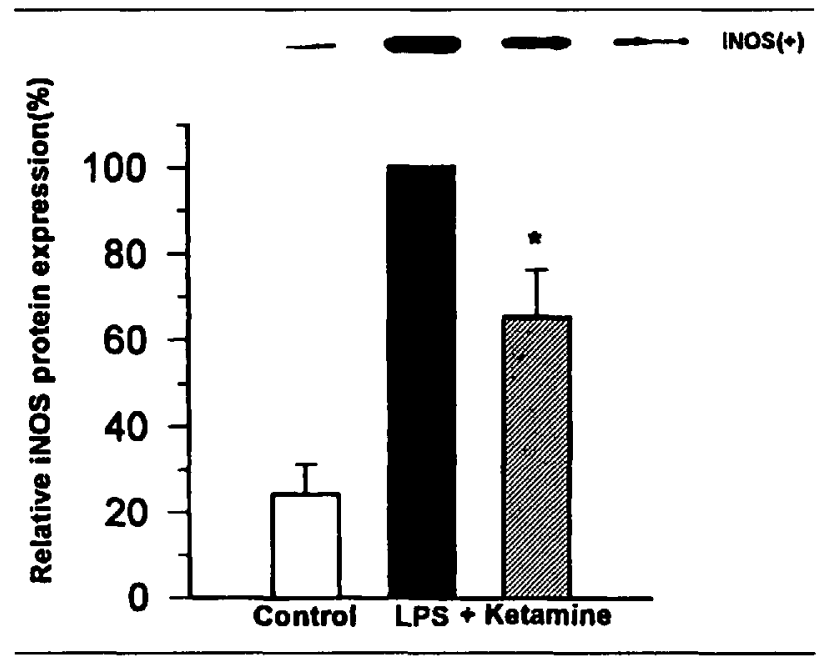

FIGURE 4 Effects of ketamine on the iNOS protein content in the supernatant of LPS-stimulated rat alveolar macrophages. The expression of iNOS was measured in macrophages un-stimulated (control; $\mathrm{n}=3$ ), treated with LPS ( $\left.1 \mu \mathrm{g} \cdot \mathrm{m}^{-1}\right)(\mathrm{LPS} ; \mathrm{n}=3$ ) or co-treated with LPS and ketamine $(100 \mu \mathrm{M})(+$ ketamine; $n=3)$ for $24 \mathrm{hr}$. The upper panel depicts a representative Western blot, and the lower panel is the statistical summary of the densitometric analysis with the reading from LPS-stimulated macrophages taken as $100 \%$.

$* P<0.05$ vs LPS alone.

nitrite and TNF- $\alpha$ in LPS-activated rat alveolar macrophages.

Septic shock is the leading cause of death in critically ill patients in the intensive care unit. It is characterized by progressive dysfunction in multiple organs following a major physiological injury. ${ }^{29}$ Although its pathophysiology is not well defined, nitric oxide from iNOS may play an important role in the organ dysfunction and circulatory failure. It has been shown that in patients with sepsis, hypotension was reversed by NOS inhibitors such as $\mathrm{N}^{\mathrm{G}}$-nitro-L-arginine methyl ester (L-NAME) or $\mathrm{N}^{\mathrm{G}}$-monomethyl-L-arginine (L-NMMA) but the patients subsequently died. ${ }^{30,31}$ This might have been due to loss of (I) the beneficial effects of cNOS, e.g., impairment of organ perfusion, or (ii) compromise of host cell immunity by inhibiting the iNOS, since most available NOS inhibitors inhibit both constitutive and inducible isoforms of NOS.6,7 In clinics, ketamine has been recommended for induction of anaesthesia and sedation in patients with circulatory shock because it preserves cardiovascular function. ${ }^{8-11}$ Here, we have demonstrated that ketamine also inhibits the activity and expression of iNOS in this study. However, the inhibitory effects of ketamine on cNOS and cellular immunity in vivo remain to be investigated and the therapeutic application of ketamine on septic patients is also needed to be carefully evaluated. 


\section{Acknowledgments}

This work was supported by a grant of the Tri-Service General Hospital, Taipei, Taiwan, R. O. C. (TSGHC86-50). The authors are grateful to Ms. Shu-Chuan Lin and Ms. Shiau-Hui Yang for their skillful technical assistance.

\section{References}

1 Moncada S, Palmer RMJ, Higgs EA. Nitric oxide: physiology, pathophysiology, and pharmacology. Pharmacol Rev 1991; 43: 109-42.

2 Forstermann U, Schmidt HHHW, Pollock JS, et al. Isoforms of nitric oxide synthase. Characterization and purification from different cell types. Biochem Pharmacol 1991; 42: 1849-57.

3 Xie Q-W, Cho HJ, Calaycay J, et al. Cloning and characterization of inducible nitric oxide synthase from mouse macrophages. Science 1992; 256: 225-8.

4 Stuebr DJ, Marletta MA. Induction of nitrite/nitrate synthesis in murine macrophages by BCG infection, lymphokines or interferon- $\gamma$. J Immunol 1987; 139: 518-25.

5 Ding AH, Nathan CF, Stuehr DJ. Release of reactive nitrogen intermediates and reactive oxygen intermediates from mouse peritoneal macrophages. Comparison of activating cytokines and evidence for independent production. J Immunol 1988; 141: 2407-12.

6 Natban CF, Hibbs JB Jr. Role of nitric oxide synthesis in macrophage antimicrobial activity. Curr Opin Immunol 1991; 3: 65-70.

7 Szabó C, Mitchell JA, Thiemermann C, Vane JR. Nitric oxide-mediated hyporeactivity to noradrenaline precedes the induction of nitric oxide synthase in endotoxin shock. Br J Pharmacol 1993; 108: 786-92.

8 White PF, Way WL, Trevor AJ. Ketamine-its pharmacology and therapeutic uses. Anesthesiology 1982; 56: 119-36.

9 Waxman K, Shoemaker WC, Lippmann $M$. Cardiovascular effects of anesthetic induction with ketamine. Anesth Analg 1980; 58: 355-8.

10 Vi-Hankala $A$, Kirvelä $M$, Randell $T$, Lindgren $L$. Ketamine anaesthesia in a patient with septic shock. Acta Anaesthesiol Scand 1992; 36: 483-5.

11 Van der Linden P, Gilbart E, Engelman E, Schmartz D, de Rood $M$, Vincent J-L. Comparison of halothane, isoflurane, alfentanil, and ketamine in experimental septic shock. Anesth Analg 1990; 70: 608-17.

12 Takenaka I, Ogata M, Koga K, Matsumoto $T$, Shigematsu $A$. Ketamine suppresses endotoxin-induced tumor necrosis factor alpha production in mice. Anesthesiology 1994; 80: 402-8.

13 Gonzales JM, Loeb AL, Reichard PS, Irvine S. Ketamine inhibits glutamate-, N-methyl-D- aspartate-, and quisqualate-stimulated cGMP production in cultured cerebral neurons. Anesthesiology 1995; 82: 205-13.

14 Shimaoka $M$, Iida $T$, Obara $A$, et al. Ketamine inhibits nitric oxide production in mouse-activated macrophage-like cells. Br J Anaesth 1996; 77: 238-42.

15 Wu C-C, Chen S-J, Szabó C, Thiemermann C, Vane JR. Aminoquanidine attenuates the delayed circulatory failure and improves survival in rodent models of endotoxic shock. Br J Pharmacol 1995; 114: 1666-72.

16 Gross SS, Levi $R$. Tetrahydrobiopterin synthesis. An absolute requirement for cytokine-induced nitric oxide generation by vascular smooth muscle. J Biol Chem 1992; 267: 25722-9.

17 Thiemermann C, Wu C-C, Szabó C, Perretti M, Vane $J R$. Role of tumour necrosis factor in the induction of nitric oxide synthase in a rat model of endotoxin shock. Br J Pharmacol 1993; 110: 177-82.

18 Szabó C, Wu C-C, Gross SS, Thiemermann C, Vane JR. Interleukin-l contribute to the induction of nitric oxide synthase by endotoxin in vivo. Eur J Pharmacol 1993; 250: 157-60.

19 Waage $A$. Production and clearance of tumor necrosis factor in rats exposed to endotoxin and dexamethasone. Clin Immunol Immunopathol 1987; 45: 348-55.

20 Zuckerman SH, Stellbaas J, Butler LD. Differential regulation of lipopolysaccharide-induced interleukin 1 and tumor necrosis factor synthesis: effects of endogenous and exogenous glucocorticoids and the role of the pituitary-adrenal axis. Eur J Immunol 1989; 19: 301-5.

21 Hattori $\Upsilon$, Kasai K, So S, Hattori S, Banba $N$, Shimoda $S-I$. Effects of calcium channel antagonists on the induction of nitric oxide synthase in cultured cells by immunostimulants. Life Sci 1995; 57: 1833-40.

22 Wu C-C, Croxtall JD, Perretti $M$, et al. Lipocortin 1 mediates the inhibition by dexamethasone of the induction by endotoxin of nitric oxide synthase in the rat. Proc Natl Acad Sci U S A 1995; 92: 3473-7.

23 Szabó C, Mitchell JA, Gross SS, Thiemermann C, Vane $J R$. Nifedipine inhibits the induction of nitric oxide synthase by bacterial lipopolysaccharide. J Pharmacol Exp Ther 1993; 265: 674-80.

24 Lo C-J, Garcia I, Cryer G, Maier RV. Calcium and calmodulin regulate lipopolysaccharide-induced alveolar macrophage production of tumor necrosis factor and procoagulant activity. Arch surg 1996; 131: 44-50.

25 Denlinger LC, Fisette $P L$, Garis $K A$, et al. Regulation of inducible nitric oxide synthase expression by macrophage purinoreceptors and calcium. I Biol Chem 1996; 271: 337-42.

$26 W u C-C, \gamma_{e n} M-H$. Beneficial effects of dantrolene on lipopolysaccharide-induced haemodynamic alternations in rats and mortality in mice. Eur J Pharmocol 1997; (in press). 
27 Schmidt $H$, Ebeling $D$, Bauer $H$, et al. Ketamine attenuates endotoxin-induced leukocyte adherence in rat mesenteric venules. Crit Care Med 1995; 23: 2008-14.

28 Lin $S-Z$, Chiou $A-L$, Wang $Y$. Ketamine antagonizes nitric oxide release from cerebral cortex after middle cerebral artery ligation in rats. Stroke 1996; 27: 747-52.

29 Parrillo JE. Pathogenetic mechanisms of septic shock. N Engl J Med 1993; 328: 1471-7.

30 Petros A, Bennett $D$, Vallance P. Effect of nitric oxide synthase inhibitors on hypotension in patients with septic shock. Lancet 1991; 338: 1557-8.

31 Petros A, Lamb G, Leone A, Moncada S, Bennett D, Vallance $P$. Effects of a nitric oxide synthase inhibitor in humans with septic shock. Cardiovasc Res 1994; 28 : 34-9. 